Doi: $10.4274 /$ vhd. 36035

Viral Hepatitis Journal 2014; 20(2): 49-56

\title{
Viral Hepatitis in Croatia
}

\section{Hıvatistan'da Viral Hepatitler}

\author{
Rok CIVLJAK1, Marina KLJAKOVIC-GASPIC2, Bernard KAIC3, Nikola BRADARIC4 \\ 1Zagreb University Fran Mihaljevic Hospital Faculty of Medicine, Department of Infectious Diseases, Zagreb, Croatia \\ 2Zagreb, Croatia \\ ${ }^{3}$ Croatian Institute of Public Health, Zagreb, Croatia \\ ${ }^{4}$ Split University Hospital Faculty of Medicine, Department of Infectious Diseases, Split, Croatia
}

\begin{abstract}
Objective: The aim of this study was to review the epidemiology of hepatitis a virus (HAV), hepatitis $B$ virus (HBV), hepatitis $C$ virus (HCV), and hepatitis D virus (HDV) infections in Croatia with emphasis on the influence on the national health and health care system.

Materials and Methods: We conducted a literature search of data on the epidemiology of viral hepatitis in Croatia with a review of national data from our reference centers.

Results: Since the year 2000, the incidence of hepatitis A in Croatia has shown a continuous and stable decline with only four cases recorded in 2012. Concerning chronic HBV infection, Croatia is classified among the countries with a low prevalence, only $<2 \%$. The prevalence of HCV infection ranges between 0.035 and $1.6 \%$. HDV infection is uncommon and the majority of infected persons are intravenous drug addicts. Vaccination against HAV has not been included in the regular vaccination calendar; only persons, who are suffering from chronic liver diseases or those traveling to highly endemic regions, are vaccinated against it. Immunization against hepatitis B was introduced in 1992 and for years was mandatory for persons at increased risk. The vaccination of adolescents was introduced in 1999, while universal mandatory vaccination of newborns was finally introduced in 2007. Like all measures for preventing and treating communicable diseases in Croatia, vaccination against hepatitis is free of charge and fully covered by health insurance for every inhabitant who is required to be vaccinated. There are serious problems concerning the treatment of hepatitis in Croatia which has been in an economic crisis for several years. The treatment of acute hepatitis is symptomatic, except in cases of hepatitis $B$ in immunocompromised persons, acute hepatitis $C$ in persons who have positive HCV RNA three months prior to the start of therapy and healthcare workers from the onset of the disease. As of this year, the protease inhibitors have been registered in Croatia. So far, approximately 30 patients have been included in triple therapy, mainly with donated medicine for treatment-naive patients with genotype 1 and relapsers following prior dual therapy with genotype 1 .

Conclusion: Enhanced understanding of viral, host, and environmental factors that influence disease progression, as well as prevention as a cornerstone, may ultimately improve the burden of viral hepatitis in Croatia. (Viral Hepatitis Journal 2014; 20(2): 49-56)
\end{abstract}

Key words: Hepatitis, viral hepatitis, hepatitis A, hepatitis B, hepatitis C, hepatitis $D$, vaccination, Croatia

\section{ÖZET}

Amaç: Bu çalışmanın amacı, ulusal sağ lık ve sağlık bakım sistemi üzerindeki etkilere odaklanarak Hırvatistan'da HAV, HBV, HCV ve HDV enfeksiyonunun epidemiyolojisini incelemekti.

Yöntemler: Referans merkezlerimizden alınan ulusal verilerin incelenmesi ile birlikte Hıvatistan'da viral hepatitin epidemiyolojisi ile ilgili bir literatür taraması yürüttük.

Bulgular: Hırvatistan'da 2000 ylından beri hepatit A insidası sürekli ve stabil bir düşüş göstermiştir; 2012'de sadece dört vaka kaydedilmiştir. Kronik HBV enfeksiyonu ile ilgili olarak Hırvatistan düşük prevalansa sahip bir ülke olarak sınıflandırılır(sadece $<\% 2$ ). HCV enfeksiyonunun prevalansı \%0,035 ile \%1,6 arasında değişir. HDV enfeksiyonu nadirdir ve enfekte kişilerin çoğu intravenöz ilaç bağımlılarıdır. HAV'e karşı aşılama düzenli aşı takvimi içine dahil edilmemiştir; sadece kronik karaciğer hastalı̆ıı olan veya yüksek düzeyde endemik olan bölgelere seyahat edecek olan kişilere aşı yapılır. Hepatit B'e karşı aşılama 1992'de başlatılmışıı ve yüksek riske sahip olan kişilerde yıllarca zorunlu olmuştur. Adölesanların aşılanmasına 1999'da başlanmıştır. Bütün yenidoğanların zorunlu olarak aşılanması 2007 yılında başlatılmıştır. Hırvatistan'da bulaşıcı hastalılıların önlenmesi ve tedavisi için alınan bütün önlemlerde olduğu gibi, hepatite karşı aşılama ücretsizdir ve aşılanması gereken her vatandaş için sağık sigortası tarafından karşılanır. Birkaç yıldır ekonomik kriz içinde olan Hırvatistan'da hepatit tedavisi ile ilgili ciddi problemler vardır. Immün sistemi baskılanmış kişilerde hepatit B enfeksiyonu vakaları, tedaviye başlamadan 3 ay önce HCV RNA pozitif olan kişilerde ortaya çıkan akut hepatit $C$ vakaları ve hastalı̆ın başlangııından itibaren sağık bakım çalışanları hariç akut hepatit tedavisi semptomatiktir. Bu yıl itibari ile Hırvatistan'da proteaz inhibitörleri tescillenmiş̧ir. Bugüne kadar yaklaşık olarak 30 hasta üçlü tedaviye dahil edilmiştir (genotip-1 olan daha önce tedavi almamış hastaların ve genotip- 1 olan ve daha önceki ikili tedaviyi takiben nüks gelişen hastaların tedavisi için bağışlanmış ilaçlarla).

Sonuç: Hastalığın ilerleyişini etkileyen viral, konak ve çevresel faktörlerin daha iyi anlaşılması ve köşe taşı olarak prevansiyon sonuçta Hırvatistan'da viral hepatit yükünü azaltabilecektir. (Viral Hepatit Dergisi 2014; 20(2): 49-56)

Anahtar Kelimeler: Hepatit, viral hepatit, hepatit A, hepatit B, hepatit C, hepatit D, aşılama, Hırvatistan 


\section{The Epidemiology of Viral Hepatitis in Croatia}

\subsection{The Epidemiology of Hepatitis A Virus (HAV) Infection in Croatia}

Hepatitis A occurs in all parts of the world, but the intensity of the problem differs significantly among geographical regions (1). While developing countries have high hepatitis A endemicity (seroprevalence in children younger than ten years of age $>90 \%$ ) (1), in countries with a high per capita gross domestic product, human development index and access to clean water, the incidence of HAV infection is low (2).

During the period from 1960 to 1969, the average annual incidence of hepatitis A in Croatia was 163 patients per 100.000 inhabitants, while it was nine patients per 100.000 inhabitants in the period from 1990 to 1999 (3). There has been a reduction in the seroprevalence of HAV infection among children younger than 15 years of age, from $18.7 \%$ in 1989 (4) to $5.6 \%$ in the $2008 / 2009$ period (5). Since the year 2000 , the incidence of hepatitis A has shown a continuous and stable decline with only four cases of HAV infection recorded in the year 2012 (6). The trend in the hepatitis A incidence rates in Croatia during the past four decades is presented in (Figure 1).

According to a national study conducted in 2008/2009, showing the seroprevalence of HAV in the general Croatian population of $41.6 \%$, and in persons younger than 30 years of age to be $4.8 \%-9.1 \%(5)$, places Croatia among the countries with very low endemicity in which the seroprevalence of persons younger than 30 years of age is below $50 \%$ (1). The results of the same study indicated that $90 \%$ of the participants under 30 years of age were susceptible to HAV infection (5).

\subsection{The Epidemiology of Hepatitis B Virus (HBV) Infection} in Croatia

Hepatitis B is a global public health problem due to the high prevalence of HBV infection in the world (7) and its clear association with cirrhosis of the liver (8) and hepatocellular carcinoma (HCC) $(8,9)$. The prevalence of HBsAg in the general population of a given geographic area is used as an indicator of the endemicity of HBV infection (10). The highest prevalence has been recorded in the region of Sub-Saharan Africa, while regions with a prevalence of $<2 \%$ include Tropical and Central Latin America, North America and Western Europe (7).

Ott et al. (7) classified Croatia among the countries with a low intermediate prevalence of $\mathrm{HBsAg}$ carriers constituting $2 \%-4 \%$ of the population, while Kaic et al. found a low prevalence of chronic HBV infection, only <2\% (11).

Nevertheless, the prevalence of HBV infection can vary significantly among individual groups. In Croatia, the most common routes of the transmission of HBV infection have been recorded as sexual contact (12), family contacts $(12,13)$, intravenous drug abuse $(12,14)$, and nosocomial exposure to infectious biological materials $(12,13,15)$. This is corroborated by the results of research in which the following groups in Croatia were determined to be at high risk: promiscuous heterosexuals, men who have sexual relations with men (MSM) $(16,17)$, those in sexual or close family contact with chronically infected persons (13), intravenous drug users (18), and healthcare workers (HCWs) $(15,19)$.

In the period from 1980 to 1984 , HCWs made up $11.9 \%$ of the hospitalized patients with acute hepatitis B in Croatia, among whom the largest number were nurses (15). According to the occupational health records of the Croatian Institute for Health Protection and Safety at Work (CIHPSW), the last case of acute occupational hepatitis $\mathrm{B}$ in a $\mathrm{HCW}$ in Croatia was recorded in the year 2008 (20).

Since it is illegal in Croatia to possess or consume psychoactive drugs, there are no reliable data on the number of addicts or the prevalence of infections transmitted by blood in this risk group. A national study conducted in 2007 confirmed a high incidence of positive markers for hepatitis $B$ in the population of intravenous drug addicts. The prevalence of anti-HBc positivity in the territory of the three largest Croatian cities was $9 \%-31 \%$, while within the national prison system it was $24 \%$ (18). This study showed that the highest incidence is in the city of Split, as also confirmed by Mulic et al., according to whom $40 \%$ of the addicts have markers indicating recovery from $\mathrm{HBV}$ infection, while $3.9 \%$ of the addicts have chronic HBV infection (21).

According to data from medical histories, the numbers of HBV-positive persons treated for addiction to psychoactive drugs in Croatia during the period from 2004 to 2011 show a downward trend: in 2004 there were $19.2 \%, 15.5 \%$ in 2006, 13.2\% in 2008, $10.4 \%$ in 2010 , and $7.3 \%$ in 2011 (22).

In the population of MSM, the seroprevalence of HBsAg indicating the carrier state was $0.8 \%$, markers of naturally acquired immunity to HBV infection $7.8 \%$, while $56.9 \%$ were susceptible to HBV infection (17).

Serological testing showed that $20 \%$ of the family members of chronic HBsAg carriers have markers of HBV infection. The greatest risk of transmission was recorded in cases when a mother was the primary HBV carrier, while the use of shared razors was recognized as the most common transmission route of infection (13).

In 1999, when mandatory testing of pregnant women in Croatia for the presence of HBsAg was introduced (23), the prevalence of $\mathrm{HBsAg}$ presence indicating the carrier state was $0.75 \%$ (24). Since then until now, the prevalence of $\mathrm{HBsAg}$ positivity among pregnant women in Croatia has continued to decline and according to the latest data is $0.2 \%$ (11).

A relatively good indicator used to determine the presence of $\mathrm{HBV}$ infection in the general population is the prevalence of $\mathrm{HBsAg}$ positivity among voluntary blood donors (VBDs). In the group of new and repeat VBDs, the prevalence of confirmed positive

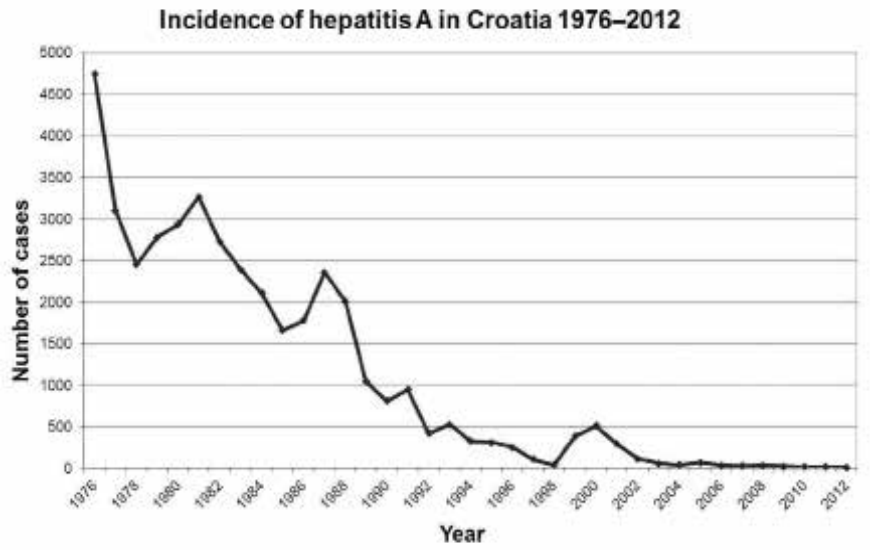

Figure 1. The incidence of hepatitis A in Croatia. 
hepatitis B markers in Croatia during the past year is very low and continues to decline (21). In the 1990s, the prevalence of HBsAg carriers (repeatedly reactive) among VBDs ranged from $0.65 \%$ in 1993 and to $0.4 \%$ in 1997, while at the end of the 1990s the prevalence was $0.1 \%-0.2 \%$ (25).

According to a report issued by the Croatian Institute of Transfusion Medicine for the year 2011, the percentage of repeatedly reactive carriers was $0.035 \%$ for all VBDs, and there were confirmed positive samples from $0.01 \%$ of all blood donors and from $0.23 \%$ of new VBDs (26). Such data indirectly indicate a decline in the number of HBV carriers among the population but should, nonetheless, be taken with reserve since blood donation in Croatia is voluntary, not paid and generally involves the healthy population, from which risk groups are excluded (drug addicts, prostitutes, etc.) (21).

On the basis of data on the prevalence of HBsAg in various population subgroups, it is estimated that in Croatia there are currently approximately 20.000 to 30.000 persons chronically infected with HBV (11).

According to the mandatory reports of communicable diseases, during the period from 1975 to 1990, the incidence of acute hepatitis B in Croatia ranged between 150 and 250 newly discovered cases per year (Figure 2). In the 1990s, owing to population migration during the Homeland War, there was an increase in the incidence of HBV infection in Croatia due to the arrival of refugees from neighboring Bosnia and Herzegovina, among whom the percentage of chronic carriers was two to three times higher than in the Croatian population (27). However, the armed conflict also led to an increase in drug addiction, crowded housing conditions and a decline in the living standard, which resulted in a peak incidence in the year 1997 (Figure 2). With the introduction of the mandatory vaccination of children 12 years of age and older (23), a drop in the incidence of acute hepatitis B was recorded, which in the past three years has been fewer than a hundred newly identified cases per year (Figure 2). We can attribute this to raised awareness of infectious diseases, the vaccination of students against hepatitis $B$ and a harm reduction program that has been implemented in Croatia since 1995/1996 (21).

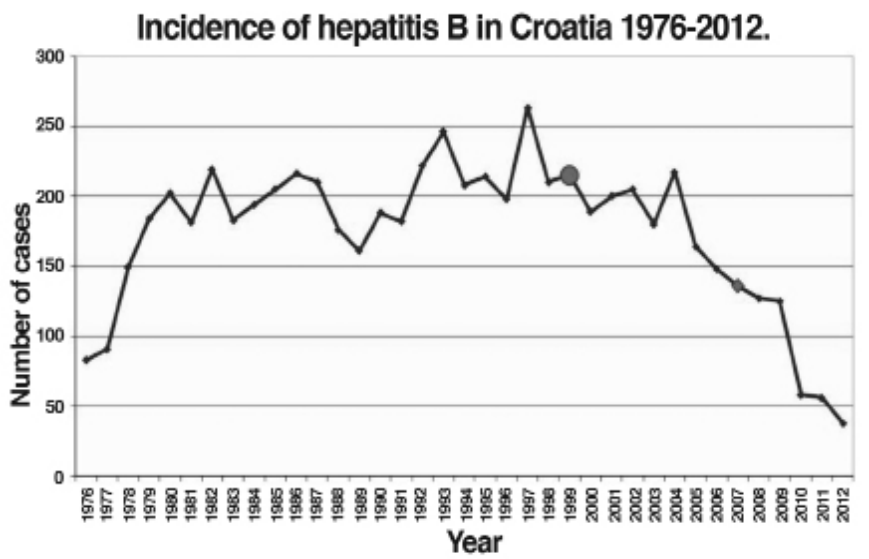

Figure 2. The incidence of hepatitis B in Croatia.

The big red dot is showing the year (1997) when vaccination against hepatitis $B$ became mandatory for students (age 12) while small foursquare is showing the year (2007) when vaccination against hepatitis B became mandatory for children in the first year of life.

\subsection{The Epidemiology of Hepatitis C Virus (HCV) Infection in Croatia}

It is estimated that $2 \%-3 \%$ of the world population is infected with HCV (28) and that approximately 350.000 people die annually from the effects of $\mathrm{HCV}$ infection, mainly due to the development of cirrhosis of the liver and HCC (29).

In the Republic of Croatia, the prevalence of HCV infection ranges between 0.035 and $1.6 \%(25,30)$. Most of the data on prevalence are obtained through the serological testing of samples from VBDs, which reveals the presence of anti-HCV antibodies. Since blood donors are a strictly controlled group, it is to be expected that the actual prevalence in the general population is even higher (31). According to reports on cases of infectious diseases of the Croatian Institute of Public Health, 200 new cases of hepatitis C in the Republic of Croatia and approximately the same number of chronic carriers of the virus are reported each year (30).

Of the total number of reported new cases of hepatitis $C$ in Croatia during the period from 1999 to 2003, approximately $46 \%$ were in the counties of Split-Dalmatia and Istria, which comprise roughly $15 \%$ of the population. Both these counties are located in the coastal region of Croatia and have the highest numbers of registered intravenous drug addicts in the country $(32,33)$.

$\mathrm{HCV}$ is transmitted directly from person to person, most often via the blood of infected persons. Outside the body, the virus can survive for up to several hours, while in blood outside the body it can even live for months. Therefore, the virus can also be transmitted via blood products, non-sterile medical supplies or organ transplant $(34,35)$. This transmission route was probably particularly significant for the Republic of Croatia during the recent war, when VBDs were not tested for HCV (36).

Infection is especially common among intravenous drug addicts. A study conducted during 2007 in the three largest Croatian cities showed a high incidence of positive HCV markers in the population of intravenous drug addicts: the prevalence of antiHCV antibodies was 29\%-65\% (18). The greatest risk factor among intravenous drug addicts is the sharing of needles. According to a study conducted in Croatia, the seroprevalence of HCV among intravenous drug addicts who occasionally shared needles was $27.3 \%$, while among intravenous drug addicts who constantly shared needles it was $100 \%$ (37).

Increased HCV seroprevalence has also been identified in Croatia among subjects who engage in risky sexual behavior: $4.9 \%$ of the men and $2.9 \%$ of the women were seropositive (38). From the 1990s to the present, the prevalence of anti-HCV carriers among new VBDs in Croatia has continued to decline. According to the most recent available data, in 2012 the prevalence of positive anti-HCV antibodies among VBDs was $0.008 \%$ (26).

Based upon the seroprevalence in various subgroups among the population, it is estimated that in Croatia, there are currently between 35.000 and 45.000 inhabitants who are chronically infected with HCV (11). Of the HCV 11 genotypes, in Croatia the most common ones are genotypes 1 (58.8\% of the patients) and 3 (35.6\% of the patients), while genotypes 2 and 4 are much more uncommon in Croatia (2.2\% and 3.4\%) (39). The trend in the hepatitis $\mathrm{C}$ incidence rates in Croatia during the past two decades is presented in Figure 3. 
1.4. The Epidemiology of Hepatitis D Virus (HDV) in Croatia

Since the discovery of HDV in the year 1977 (40), it has been recognized as a serious medical problem due to its marked pathogenicity and association with severe and rapidly progressive forms of liver disease (41). HDV infection is transmitted parenterally (mainly by infected blood), through sexual contact, close contacts and perinatally, but overall is significantly less common than HBV infection.

Studies from the 1980s showed that HDV infection is present in all parts of the world, although not with the same frequency. At that time, it was estimated that there were approximately 15.000.000 HDV carriers worldwide (42). In Croatia, HDV infection is uncommon (43). In one Croatian general hospital, among $100 \mathrm{HBV}$-positive patients with chronic liver disease, 19\% also had positive markers for HDV infection. The majority of them were intravenous drug addicts and HDV infection was associated with serious clinical and histological forms of chronic liver disease $(89.5 \%$ had chronic active hepatitis and cirrhosis, while 19.5\% had chronic persistent hepatitis) (44).

\section{The Immunization Policies for Hepatitis A and B in Croatia}

In Croatia, vaccination against hepatitis A has not been included in the regular vaccination calendar; only persons who have not had hepatitis $A$ and are suffering from certain chronic liver diseases or who are traveling to highly endemic regions of the world are vaccinated against it.

On the other hand, immunization against hepatitis B was introduced in the year 1992. In the beginning, it was mandatory only for persons at increased risk of HBV infection: healthcare workers, newborns with HBsAg-positive mothers, patients on hemodialysis, sexual partners of HBsAg-positive persons, personnel working in institutions for mentally challenged persons, intravenous drug addicts, and patients suffering from hemophilia $(45,46)$.

In 1992, the World Health Organization recommended that immunization against HBV should be introduced in national programs for the mandatory vaccination of children (47). However, in Croatia, the vaccination of children was only introduced in 1999, which was for adolescents of 12 years of age or older (23). This decision was made on the basis of data on the highest incidence of disease during adolescence and the small risk of disease during childhood (48), thus, the aim was to protect young people from acquiring HBV infection before entering the age when they

Incidence of hepatitis C in Croatia 1992-2012.

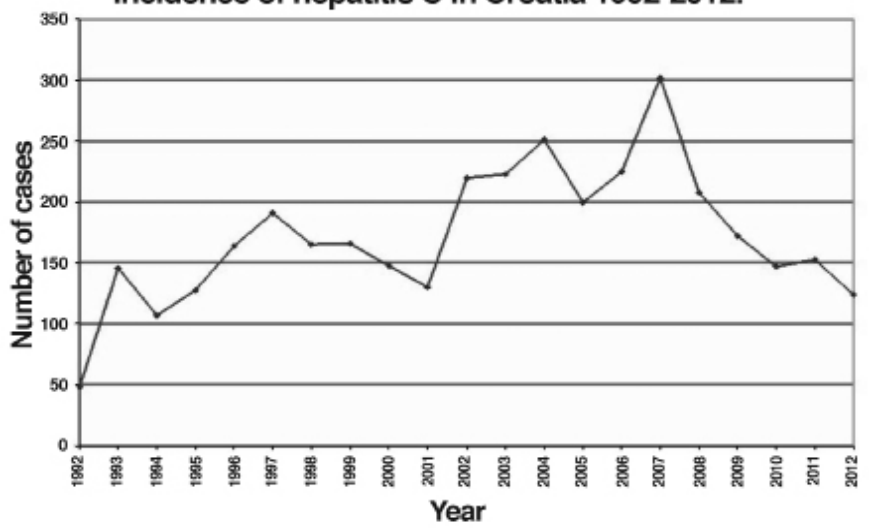

Figure 3. The incidence of hepatitis B in Croatia. would be at risk, i.e., before they began to engage in sexual activity and eventual drug use (21). The same year, mandatory testing of all pregnant women for HBsAg was introduced (23). In 2004, mandatory vaccination was extended to include the family members of HBsAg-positive persons and those with leukemia (49). Universal mandatory vaccination of newborns against hepatitis B was finally introduced in 2007 (50). Since then, all the children in Croatia are vaccinated against hepatitis $B$.

In the ten years since the introduction of mandatory vaccination against hepatitis in Croatia, there has been a $56 \%$ reduction in the incidence of acute hepatitis B (51). If we take the fact that vaccination coverage is over $95 \%$ into account, these results can be attributed to the systematic and very thorough implementation of the vaccination program in our country (6). The success of vaccination against hepatitis $\mathrm{B}$ during preadolescence is clearly illustrated by the marked decline in the incidence and prevalence of hepatitis precisely in the age groups who received vaccinations, i.e., persons who are now 15 to 25 years of age (Figure 4).

\section{National Reimbursement Policy, Problematic Issues}

Like all measures for preventing and treating communicable diseases in Croatia, vaccination against hepatitis is free of charge and fully covered by health insurance for every inhabitant who is required to be vaccinated $(52,53)$. However, while vaccination against hepatitis $B$ has been introduced in the mandatory vaccination schedule during childhood and the entire population is now vaccinated $(23,50)$, this is not the case with vaccination against hepatitis $A$. Since Croatia is low endemic for hepatitis $A$, in the future, hepatitis $A$ will mainly occur in older age groups. Therefore, a strategy should be developed to identify at-risk populations in order to protect them from developing hepatitis $\mathrm{A}$, which among the elderly has higher mortality and greater need for treatment than among children. There are also problems concerning indications for treatments that do not cover the entire population of persons infected with hepatitis viruses (54-57).

There are serious problems concerning the treatment of hepatitis in Croatia, which has been in an economic crisis for several years. The treatment of acute hepatitis is symptomatic, except in cases of hepatitis B in immunocompromised persons, acute hepatitis C in persons who have positive HCV RNA three months prior to the

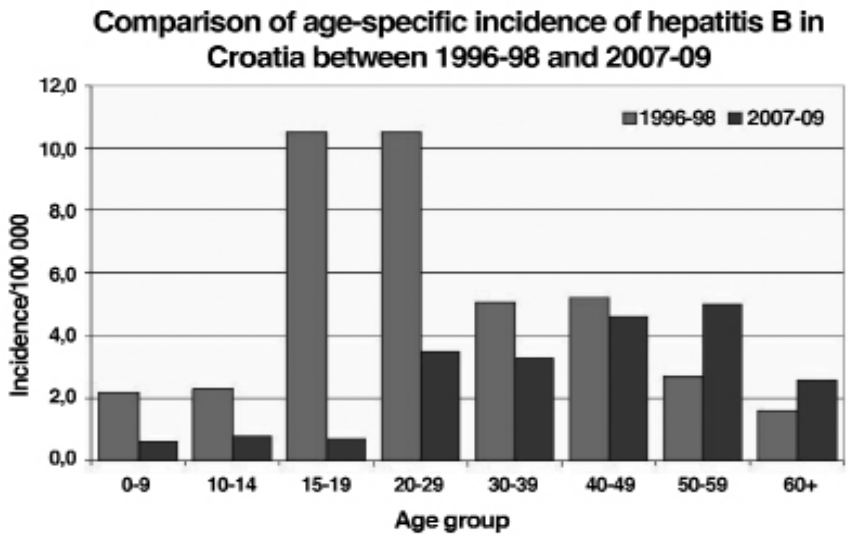

Figure 4. Comparison of age-specific incidence of hepatitis $B$ in Croatia between 1996-98 and 2007-09. 
start of therapy and HCWs from the onset of the disease. The gold standard for the treatment of acute fulminant hepatitis is a liver transplantation, and here there is no waiting on the transplant list but the surgery is performed immediately. In the event that there is no suitable donor, sometimes off-label therapy with prostaglandin E2 is tried. In our country, the success rate for curing patients in stage 4 coma is $60 \%$ for a small series of patients (58). In Croatia, chronic hepatitis $B$ is treated with nucleoside/nucleotide analogues (NAs) and pegylated interferon alpha-2a. The registered NAs are lamivudine, telbivudine and tenofovir, and with emergency import it is also possible to procure adefovir and entecavir. In the latest consensus, the use of NAs with little potential for the development of resistance (tenofovir and entecavir) is preferred. The use of telbivudine and pegylated interferon alpha-2a is financed by the fund for especially expensive drugs. Treatment is conducted according to the guidelines of the Croatian Consensus Conference on Viral Hepatitis of 2013 and the guidelines of the Croatian Health Insurance Fund, which pays for the cost of treatment (59). Unfortunately, the results of treatment are poor and transient, partially because the HBV genotype D and patients who are $\mathrm{HBsAg}(+)$ and anti $\mathrm{HBe}$ $(+)$ predominate in Croatia. HBsAg (+) persons for whom liver transplantation is indicated due to $\mathrm{HCC}$ or cirrhosis are treated with NAs in order to reduce HBV viremia, with the idea that the risk of reinfection should be as low as possible during the post-transplant period. After transplantation, hepatitis $B$ immune globulin $(H B I G)$ is given in addition to NAs, according to the protocol defined by the guidelines of the Croatian Consensus Conference on Viral Hepatitis (59). HBIG therapy is begun during the anhepatic phase of surgery and continues every day during the first week post-transplantation, and subsequently, depending on the level of anti-HBs that remain after the first month post-transplantation in excess of $100 \mathrm{IU} / \mathrm{L}$. In order to reduce costs, it is possible to replace intravenous HBIG with intramuscular, which has entered into the guidelines of the Asian-Pacific consensus statement on the management of chronic hepatitis B: a 2012 update (60).

Chronic hepatitis $C$ in patients between 18 and 70 years of age is treated with a combination of pegylated interferon alpha-2a/alpha $2 \mathrm{~b}$ and ribavirin for a duration of 24 weeks for genotypes 2 and 3 or 48 weeks for genotypes 1 and 4, provided that there has been a 2-log (at least 100x) reduction in viremia after 12 weeks. Genotypes 5 and 6 are not present in Croatia. If the fibrosis score is $>5$ according to Ishak or 4 according to METAVIR, treatment for genotypes 2 and 3 lasts for 48 weeks, and 72 weeks for genotypes 1 and 4 . Patients with genotype 1 who have viremia $<600.000 \mathrm{IU} / \mathrm{ml}$ are treated for 24 weeks instead of 48 if they have a fibrosis score of $<5$ according to Ishak or $<4$ according to METAVIR and if they have a rapid virologic response (RVR) (defined as undetectable HCV RNA at week 4 of treatment). If they have a fibrosis score of $>5$ according to Ishak or $>4$ according to METAVIR and if they do not have a RVR, they are treated as patients with high viremia (55). According to the new national guidelines, in treatment-naive patients with advanced fibrosis, as well as in patients with moderate fibrosis and unfavorable predictors of treatment outcome, triple therapy including protease inhibitor (boceprevir or telaprevir) is recommended for the treatment of chronic hepatitis C genotype 1 (59). The prerequisites for treatment are as follows: <70 years of age, abstinence from drugs and alcohol for $>12$ months, a fibrosis score of $>2$ according to Ishak, and two consecutive measurements of elevated transaminase. In the new guidelines, instead of liver biopsy to evaluate the fibrosis stage, fibroelastography (commercially known as FibroScan) can be used as an alternative method. Therapy is not recommended for patients with fulminant hepatitis, patients with normal ALT without the presence of fibrosis, patients with a renal transplant, and pregnant women (61). Approximately 400 to 500 patients with chronic hepatitis $\mathrm{C}$ are treated annually in Croatia.

\section{National Prevention Strategies}

Since hepatitis A virus infection is uncommon in Croatia, vaccination against hepatitis $A$ has not been included on the regular vaccination calendar. In Croatia, the only persons vaccinated against hepatitis $A$ are those who have chronic liver disease, regardless of its cause, persons who are travelling to highly endemic regions of the world and on request (62), providing that the persons have not previously had hepatitis A. Moreover, vaccination against HAV infection is also carried out in cases of epidemiological indications, such as stopping an epidemic, and for the purpose of combating an epidemic (post-exposure immunoprophylaxis) (3). According to the program of mandatory vaccination in Croatia, immunization against hepatitis $B$ is required for certain risk groups in the adult population, adolescents and, since 2007, for children in the first year of life, which will protect all future generations. The risk groups covered by the program of mandatory vaccination include all persons employed in healthcare institutions, patients on hemodialysis, sexual partners of $\mathrm{HBsAg}$-positive persons, individuals in family contact with HBsAgpositive persons, employees of legal and physical persons that provide accommodations to persons with mental and intellectual disabilities, intravenous drug addicts, patients with hemophilia and leukemia, and newborns with HBsAg-positive mothers because all pregnant women undergo mandatory testing for HBsAg (63).

Immunization against hepatitis $B$ virus is performed using a vaccine obtained from a surface antigen of the hepatitis $B$ virus through genetic engineering that is intramuscularly administered in three doses according to a scheme on the first, thirtieth and one hundred eightieth days after indications have been determined (0, 1 and 6 months). In the event that a mother is HBsAgpositive, immunization of her newborn is administered in four doses according to a scheme of 0, 1, 2 and 6 months. For the immunization of patients on hemodialysis and those with impaired immune systems, a double dose is given based upon age (63).

For persons, who during the performance of their work come into direct contact with infected people and infected material, the antibody levels must be determined 30-60 days after receiving the third dose of vaccine against hepatitis B. If a protective level of antibodies ( $>10 \mathrm{lU} / \mathrm{L}$ ) is found, a person is considered to be protected from hepatitis $B$ and further vaccination is unnecessary. If a person does not have a protective level of antibodies, it is necessary to repeat the entire vaccination scheme of three doses. Moreover, 30-60 days after the third dose, it is necessary to check the antibody titer again. If patients do not have a protective antibody titer even after the repetition of the vaccination scheme, they are considered to be nonreactive and in the event of contact with infectious material they should receive passive immunoprophylaxis (63).

In Croatia, the manner of conducting post-exposure prophylaxis of hepatitis B depends on the HBsAg status of the source and 
the vaccination status of the exposed person, and consists of the administration of human hepatitis B immunoglobulin (HBIG) and vaccination against hepatitis $B$ according to the scheme of $0,1,2$ and 12 months. Following percutaneous exposure, a person should preferably receive immunoprophylaxis within 24 hours, and no later than within seven days (63).

The Croatian consensus on the treatment of hepatitis recommends the following procedure for the prophylaxis of HBV reactivation: For persons for whom immunotherapy (especially rituximab-plus-corticosteroid) or chemotherapy is planned, it is necessary to perform $\mathrm{HBsAg}$ and anti-HBc testing due to the high risk of the reactivation of HBV infection. Seronegative (HBsAg $(-)$ and anti-HBs $(-)$ persons should be vaccinated with larger (double) doses of vaccine due to the weaker response in the immunocompromised. HBsAg (+) persons for whom chemotherapy and immunotherapy are planned should have HBV DNA testing performed and receive NA, regardless of the level of viremia for the duration of immunotherapy or chemotherapy and for an additional 12 months after the therapy is discontinued. Lamivudine remains a therapeutic option if short-term immunotherapy or chemotherapy is planned for a patient with low viremia (<2000 IU/ $\mathrm{mll}$ ), with a reduced risk of reactivation and associated morbidity and mortality. In patients with high viremia on long-term or repeated immunotherapy or chemotherapy, it is better to give tenofovir and entecavir due to the high threshold for resistance development. HBsAg (-) anti-HBc (+) persons with demonstrable HBV DNA (occult HBV infection) should be treated in the same manner as HBsAg $(+)$ persons $(60,64,65)$.

If negative for HBV DNA, regardless of the level of anti-HBs, such patients should be closely monitored during chemotherapy and immunotherapy (measurement of HBV DNA and ALT levels every 1-3 months) and NA should be given if there is evidence of a reactivation of HBV infection before there is an increase in ALT $(64,65)$. Some experts recommend that everyone should be given NA who is HBsAg (-) anti HBc (+) who receives rituximab and/or combined therapy for hematological malignomas if HBV DNA is not closely monitored. Prophylaxis is also recommended for anti- HBC $(+)$ persons who undergo transplantation of bone marrow or stem cells, although the optimal duration of prophylaxis is not specified. If a HBsAg (-) person receives a liver transplant from a anti-HBc (+) person, unlimited prophylaxis with lamivudine is required $(64,65,66)$. Interferon should be avoided due to suppression of the bone marrow.

Unfortunately, there is no vaccine against hepatitis $C$, thus, we are left with the general measures of protection and treatment for chronic carriers in order to reduce the reservoir of infection and incidence of this disease. In addition to the dual therapy in use until now, the protease inhibitors boceprevir and telaprevir have been registered in Croatia as of this year (59). So far, approximately 30 patients have been included in triple therapy, mainly with donated medicine for treatment-naive patients with genotype 1 and relapsers following prior dual therapy with genotype 1. A limiting factor for the use of protease inhibitors, which are also financed by the fund for especially expensive drugs, is their price (approximately 28.000 EUR per patient without the cost of interferon and ribavirin).

Systematic vaccination against hepatitis B, as stated above, also prevents hepatitis $D$.

\section{Acknowledgments}

The authors also thank Mrs. Margaret Casman-Vuko for translating this paper from Croatian into English.

\section{Conflict of interest: None declared.}

\section{References}

1. Jacobsen $\mathrm{KH}$, Wiersma ST. Hepatitis A virus seroprevalence by age and world region, 1990 and 2005. Vaccine. 2010;28:6653-

2. Jacobsen $\mathrm{KH}, \mathrm{Koopman} \mathrm{JS}$. The effects of socioeconomic development on worldwide hepatitis A virus seroprevalence patterns. Int J Epidemiol. 2005;34:600-9.

3. Kaic B, Borcic B, Ljubicic M, Brkic I, Mihaljevic I. Hepatitis A control in a refugee camp by active immunization. Vaccine. 2001;19:3615-9.

4. Puntaric D, Vodopija I, Baklaic Z, Ljubicic M. [Immunity against hepatitis $A$ in younger age groups and the basis for an immunization program]. Lijec Vjesn. 1995; 117(7-8): 167-72.

5. Vilibic-Cavlek $T$, Kucinar J, Ljubin-Sternak $S$, Kolaric B. Seroepidemiology of hepatitis a in the croatian population. Hepat Mon. 2011;11:997-9.

6. Poljicanin $T$, Benjak $T$ (eds.), Croatian health service yearbook 2012. Zagreb: Croatian National Institute of Public Health; 2012. p.185-8. http://hzjz.hr/wp-content/uploads/2013/11/ Ljetopis_2012.pdf

7. Ott JJ, Stevens GA, Groeger J, Wiersma ST. Global epidemiology of hepatitis B virus infection: new estimates of age-specific HBsAg seroprevalence and endemicity. Vaccine. 2012;30:22129.

8. Iloeje UH, Yang HI, Su J, Jen CL, You SL, Chen CJ. Predicting cirrhosis risk based on the level of circulating hepatitis $B$ viral load. Gastroenterology. 2006;130:678-86.

9. Iloeje UH, Yang HI, Jen CL, Su J, Wang LY, You SL, et al. Risk and predictors of mortality associated with chronic hepatitis $\mathrm{B}$ infection. Clin Gastroenterol Hepatol. 2007;5:921-31.

10. Shepard CW, Simard EP, Finelli L, Fiore AE, Bell BP. Hepatitis B virus infection: epidemiology and vaccination. Epidemiol Rev. 2006;28:112-25

11. Kaic B, Vilibic-Cavlek T, Kurecic Filipovic S, Nemeth Blazic T, Pem Novosel I, Visekruna Vucina V. Epidemiology of viral hepatitis. Acta Med Croatica. 2013;67:273-9.

12. Brncic N, Modric M, Pahor D. Hepatitis A, B and C in Primorskogoranska County from 2001 to 2010. Medicina Fluminensis. 2012;48:213-21.

13. Milas J, Ropac D, Mulic R, Milas V, Valek I, Zoric I, et al. Hepatitis B in the family. Eur J Epidemiol. 2000;16:203-8.

14. Kolovrat A, Jurisic I, Maric Z, Cvitkovic A. Prevalence of hepatitis $B$, hepatitis $C$ and HIV among injecting drug users treated outpatiently and in therapeutic community in BrodPosavina County, Croatia. Acta Med Croatica. 2010;64:287-96.

15. Palmovic D. Acute hepatitis B in the Zagreb region. Lijec Vjesn. 1987;109:211-6

16. Bozicevic I, Rode OD, Lepej SZ, Johnston LG, Stulhofer A, Dominkovic $Z$, et al. Prevalence of sexually transmitted infections among men who have sex with men in Zagreb, Croatia. AIDS Behav. 2009;13:303-9.

17. Bozicevic I, Zidovec Lepej S, Dakovic Rode O, Grgic I, Jankovic P, Dominkovic Z, et al. Prevalence of HIV and sexually transmitted infections and patterns of recent HIV testing among men who have sex with men in Zagreb, Croatia. Sex Transm Infect. 2012:88:539-44 
18. Kolaric B, Stajduhar D, Gajnik D, Rukavina T, Wiessing L. Seroprevalence of blood-borne infections and population sizes estimates in a population of injecting drug users in Croatia. Cent Eur J Public Health. 2010;18:104-9.

19. Ropac D, Zoric I, Palmovic D, Mulic R, Milas J, Stasevic I. The prevalence of hepatitis $B$ virus infection among medical workers prior to vaccination. Periodicum Biologorum. 2001;103:45-8.

20. Registar profesionalnih bolesti Hrvatskog zavoda za zastitu zdravlja i sigurnost na radu. Zagreb: Croatian Institute for Health Protection and Safety at Work; 2008. p.11. http:// www.hzzzsr.hr/images/documents/profesionalne \% 20bolesti/ Registar\%20profesionalnih\%20bolesti\%20HZZZSR/Registar_ profesionalnih_bolesti_2008.pdf

21. Mulic R, Uglesic L, Klismanic Z, Ropac D, Smoljanovic $M$, Mratinovic-Mikulandra $J$, et al. Epidemiologic characteristic of hepatitis B in the Splitsko-Dalmatinska County. Lijec Vjesn. 2006;128: 65-71.

22. Katalinic D, Kuzman M, Markelic M, Mayer D (eds.), Izvjesce o osobama lijecenim zbog zlouporabe psihoaktivnih droga u Hrvatskoj u 2011. godini. Zagreb: Croatian National Institute of Public Health; 2012. p.34. http://hzjz.hr/wp-content/ uploads/2013/11/ovisnici2011.pdf

23. The Ministry of Health: Ordinance on the manner of carrying out immunization, seroprophylaxis and chemoprophylaxis against communicable diseases, and on the persons subject to this obligation, Pub. L. No. 534-04-03/99-0001, Stat 4 (June 18, 1999). Official Gazette 62/1999. http://narodne-novine.nn.hr/ default.aspx

24. Ivic I, Banovic I, Bradaric N. Hepatitis B virus infection among pregnant women in Split region. Eur J Epidemiol. 1999;15:58990.

25. Grgicevic D, Balija M, Pirc-Tiljak D, Mihaljevic I, GjeneroMargan I, Zupancic-Salek S, et al. Decreasing risk of viral transfusion-transmitted diseases in Croatia. Croat Med J. 2000;41:191-6.

26. Balija M, Ocic T, Vuk T, Herceg M, Jukic I (eds.), Izvjesce o rezultatima rada transfuzijske djelatnosti u Hrvatskoj u 2011. godini. Zagreb: Croatian Institute of Transfusion Medicine; 2012. http://www.hztm.hr/glasilo/52/izvjesce-o-rezultatimarada.html.

27. Palmovic D. Virusni hepatitis. Zagreb: Skolska knjiga; 1995.

28. Global Burden Of Hepatitis C Working Group. Global burden of disease (GBD) for hepatitis C. J Clin Pharmacol. 2004;44:20-9.

29. Averhoff FM, Glass N, Holtzman D. Global burden of hepatitis C: considerations for healthcare providers in the United States. Clin Infect Dis. 2012;55:10-5.

30. Lesnikar V. Epidemiology of hepatitis B and C in Croatia. Acta Med Croatica. 2005;59:377-81.

31. Alter MJ, Kruszon-Moran D, Nainan OV, McQuillan GM, Gao F Moyer LA, et al. The prevalence of hepatitis $C$ virus infection in the United States, 1988 through 1994. N Engl J Med. 1999;341:556-62.

32. Ticac B, Rukavina T. Seroloska dijagnostika hepatitis $C$ virusne infekcije - stanje u Primorsko-goranskoj zupaniji. Medicina. 2007;43:123-31.

33. Calkic L, Golubovic S, Bajramovic-Omeragic L, Tandir S, Hadzic E. Rijetki putevi prijenosa hepatitisa C. Infektoloski Glasnik. 2012;32:7-16.

34. Charlton M. Natural history of hepatitis $C$ and outcomes following liver transplantation. Clin Liver Dis. 2003;7:585-602.

35. WHO. Hepatitis C Assays: Operational Characteristics report 2. Geneva: WHO, 2001

36. Ostojic R. Hepatitis C. Medicus. 2006;15:113-20.
37. Vilibic Cavlek T, Maric J, Katicic L, Kolaric B. Hepatitis C virus antibody status, sociodemographic characteristics, and risk behaviour among injecting drug users in Croatia. Cent Eur J Public Health. 2011;19:26-9.

38. Vilibic Cavlek T. Seroprevalencija i faktori rizika za infekciju virusom hepatitisa $\mathrm{C}$ u skupinama rizicnog spolnog ponasanja. Zagreb, Croatia: University of Zagreb, 2009. Dissertation.

39. Vince A, Iscic-Bes J, Zidovec Lepej S, Baca-Vrakela I, Bradaric $\mathrm{N}$, Kurelac I, et al. Distribution of hepatitis $C$ virus genotypes in Croatia-a 10 year retrospective study of four geographic regions. Coll Antropol. 2006;30:139-43.

40. Rizzetto M, Canese MG, Arico S, Crivelli O, Trepo C, Bonino F, et al. Immunofluorescence detection of new antigen-antibody system (delta/anti-delta) associated to hepatitis B virus in liver and in serum of HBsAg carriers. Gut. 1977;18:997-1003.

41. Rizzetto M, Verme G, Recchia S, Bonino F, Farci P, Arico S, et al. Chronic hepatitis in carriers of hepatitis B surface antigen, with intrahepatic expression of the delta antigen. An active and progressive disease unresponsive to immunosuppressive treatment. Ann Intern Med. 1983;98:437-41.

42. Rizzetto M, Ponzetto A, Forzani I. Hepatitis delta virus as a global health problem. Vaccine. 1990;8:10-4

43. Vince A. Virusni hepatitis kao spolno prenosiva bolest. Medicus. 2003;12:231-6.

44. Jelic D, Jelic O. Epidemiological characteristics of HBV and HDV chronic liver diseases. Acta Med Croatica. 1994;48:7-13.

45. The Croatian Parliament: The Protection of the Population from Communicable Diseases Act of 1992, Pub. L. No. PA4-71/1-92, Stat 42 (October 1, 1992). Official Gazette 60/1992.

46. The Ministry of Health: Ordinance on the manner of carrying out immunization, seroprophylaxis and chemoprophylaxis against communicable diseases, and on the persons subject to this obligation, Pub. L. No. 534-02-22/94-0001, Stat 31 (March 25, 1994). Official Gazette 23/1994.

47. Immunization and vaccine quality, Resolution WHA 45.17. (1992).

48. Lesnikar V. Prevention of hepatitis B and C. Acta Med Croatica. 2005; 59:383-8.

49. The Ministry of Health: Ordinance on the manner of carrying out immunization, seroprophylaxis and chemoprophylaxis against communicable diseases, and on the persons subject to this obligation, Pub. L. No. 534-04-03/2-04-2, Stat 32 (November 26, 2004). Official Gazette 164/2004.

50. Kaic B, Gjenero-Margan I, Aleraj B, Nemeth-Blazic T, Baklaic Z, Ljubicic M, et al. Promjene u Programu obveznih cijepljenja u Republici Hrvatskoj u 2008. godini. Hrvatski casopis za javno zdravstvo. 2008;4.

51. Kaic B. Impact of vaccination on vaccine-preventable disease burden in Croatia. Periodicum Biologorum. 2012;114:141-7.

52. Croatian Health Insurance Fund. http://www.hzzo.hr/zdravstvenisustav-rh/kosarica-beneficija

53. Kaic B, Gjenero-Margan I, Brzovic M, Lakoseljac D, Aleraj B, Nemeth-Blazic T. Vaccine regulations in Croatia. Coll Antropol. 2007;31:117-20.

54. Bradaric N, Pavic I, Kuzmicic N, Bradaric I. Hepatitis B: who should be treated?. Acta Med Croatica. 2009;63:385-9.

55. Ostojic R, Vince A, Hrstic I, Zidovec Lepej S, Begovac J, Bradaric $\mathrm{N}$, et al. [Viral hepatitis. Croatian consensus conference--2009]. Acta Med Croatica. 2009;63:349-57.

56. Stimac D, Bradaric N, Milic S. Hepatitis C--who should be treated?. Acta Med Croatica. 2009;63:403-8.

57. Vucelic B, Hrstic I, Begovac J, Bradaric N, Burek V, Colic-Cvrlje V, et al. [Viral hepatitis: Croatian consensus statement]. Acta Med Croatica. 2005;59:359-75. 
58. Bradaric N. Akutni virusni hepatitis. In: Hozo I, Mise S (eds), Odabrana poglavlja iz gastroenterologije. Split: Hrvatsko gastroenterolosko drustvo - ogranak Split; 1999. p.237-49.

59. Vince A, Hrstic I, Begovac J, Bradaric N, Colic-Cvrlje V, Duvnjak M, et al. Viral hepatitis. Croatian consensus statement 2013. Acta Med Croatica. 2013;67:263-72.

60. Liaw YF, Kao JH, Piratvisuth T, Chan HLY, Chien RN, Liu CJ, et al. Asian-Pacific consensus statement on the management of chronic hepatitis B: a 2012 update. Hepatol Int. 2012;6:531-61.

61. Stimac D, Bradaric N, Milic S. Hepatitis C: Who Should be Treated? Acta Med Croatica. 2013;67:325-8.

62. Micovic V, Cattunar A, Stimac D, Capak K, Stojanovic D, Jurisic D. Emerging risk for viral hepatitis A in Croatian adults. Med Glas (Zenica). 2010;7:169-72.
63. The Ministry of Health: Ordinance on the manner of carrying out immunization, seroprophylaxis and chemoprophylaxis against communicable diseases, and on the persons subject to this obligation, Pub. L. No. 534-10-1-1-1/3-13-2, Stat 33-34 (August 9, 2013). Official Gazette 103/2013.

64. Bradaric N. Prophylaxis and therapy of hepatitis B after liver transplantation. Acta Med Croatica. 2005;59:433-41.

65. European Association For The Study Of The Liver. EASL clinical practice guidelines: Management of chronic hepatitis B virus infection. J Hepatol. 2012;57:167-85.

66. Cholongitas E, Papatheodoridis GV, Burroughs AK. Liver grafts from anti-hepatitis $B$ core positive donors: a systematic review. J Hepatol. 2010;52:272-9. 